\title{
Immunomodulatory and antimicrobial effects of selected herbs on laying hens
}

\author{
Mirta Balenović1, Vladimir Savić1, Zlatko Janječićé, Maja Popović́, \\ Borka Šimpraga $^{1}$, Klaudija Carović-Stanko ${ }^{3}$, Dalibor Bedeković \\ and Tajana Amšel Zelenika ${ }^{1 *}$ \\ ${ }^{I}$ Poultry Centre, Croatian Veterinary Institute, Zagreb, Croatia \\ ${ }^{2}$ Department of Animal Nutrition, Faculty of Agriculture, University of Zagreb, Zagreb, Croatia \\ ${ }^{3}$ Department of Seed Science and Technology, Zagreb, Croatia \\ ${ }^{4}$ Department of Biology, Faculty of Veterinary Medicine, University of Zagreb, Zagreb, Croatia
}

\begin{abstract}
BALENOVIĆ, M., V. SAVIĆ, Z. JANJEČIĆ, M. POPOVIĆ, B. ŠIMPRAGA, K. CAROVIĆ-STANKO, D. BEDEKOVIĆ, T. AMŠEL ZELENIKA: Immunomodulatory and antimicrobial effects of selected herbs on laying hens. Vet. arhiv 88, 673-686, 2018.
\end{abstract}

\section{ABSTRACT}

The aim of the study was to investigate the efficiency of feed supplementation with dried calendula $(C$. officinalis), dandelion (T. officinale) and marigold (T. erecta) flowers, as well as dried basil (O. basilicum 'Genovese') leaves on the kinetics of the total leukocytes, helper and cytotoxic T lymphocytes, and B lymphocytes in peripheral blood, as well as on intestinal excretion of Escherichia coli in laying hens. Laying hens of Tetra SL line, aged 25 weeks, were used in the study. The animals were divided into nine groups of 15 birds. The laying hens were fed common feed with the addition of $1 \%(10 \mathrm{~g} / \mathrm{kg})$ and $3 \%(30 \mathrm{~g} / \mathrm{kg})$ chopped flowers or leaves of the above mentioned herbs. The immunomodulatory and antimicrobial effects of medicinal herbs in laying hens were estimated by the above mentioned parameters determined at the beginning of the experiment and on day 14 and day 28 of the study, i.e. at the birds' ages of 25,27 and 29 weeks. The study results showed that the addition of chopped calendula and dandelion flowers to laying hen feed stimulated proliferation of total leukocytes as well as T and B lymphocytes, particularly in the groups receiving 3\% chopped herbs $(\mathrm{P}<0.01)$. All study herbs were found to have antimicrobial activity. The results obtained definitely confirm the favorable impact of adding herbs to hen feed because of their antimicrobial and immunostimulatory effects. Phytogenic feed additives exert favourable effects, however, knowledge of their use in poultry feed is still inadequate, thus requiring additional research. It was concluded that phytobiotics might be combined with other feed additives such as probiotics or prebiotics, in order to attain better results in poultry production.

Key words: medicinal herbs; immunostimulatory effect; antibacterial effect; laying hens

\footnotetext{
${ }^{*}$ Corresponding author:

Tajana Amšel Zelenika, PhD, Croatian Veterinary Institute, Poultry Centre, Heinzelova 55, 10000 Zagreb, Croatia, Phone: +385 12440 209; Fax: +385 12441 396; E-mail: tajana.amsel-zelenika@zg.t-com.hr
} 
M. Balenović et al.: Immunomodulatory and antimicrobial effects of selected herbs on laying hens

\section{Introduction}

General food safety, climate changes, emergence of new infectious diseases, the ban on the use of antibiotic agents (European Community Regulation No. 1831/2003 of the European Parliament and of the Council), and the ever growing and demanding intensive production pose daily challenges to poultry production. A functional immune system is a precondition for animal health. Feeding is one of the immune system modulators and appropriate balance of nutritive ingredients is of utmost importance for proper animal immune system development and maintenance. Possible immune system modulation by alternative feed additives has recently been extensively investigated in order to reduce the prevalence of infectious diseases, and improve productivity in poultry production (KOUTSOS and KLASING, 2008; FERKET, 2004). Studies have shown that active changes in poultry intestinal microflora can accelerate intestinal maturation and increase resistance to infections caused by various causative agents. Constituents found in the leaves, stalks, seeds and roots of particular medicinal plants have been frequently and efficiently involved in fighting infectious diseases and improving digestion (ASHAYERIZADEH et al., 2009; RAHIMI et al., 2011; JANKOWSKI et al., 2014). Active substances from the plants favour endogenous enzyme excretion, improve appetite and the digestibility and absorption of nutritive ingredients, improve the intestinal microflora balance, reduce the population of Escherichia coli (E. coli) and Clostridium bacteria, while stimulating Lactobacillus spp. proliferation, exerting antibacterial and antiviral effects, and stimulating the immune system (JAMROZ, 2005; WINDISCH et al., 2008).

Active substances from medicinal plants, i.e. phytobiotics, have favourable effects on animal health and productivity. Whole plants, parts of plants and essential oils have been used as phytobiotics (GRASHORN, 2010). YANG et al. (2009) and FALLAH et al. (2013) report that antimicrobial activity and immunostimulatory activity are probably the two main mechanisms by which phytobiotics elicit their beneficial effects on the economic growth and health of animals. However, there are few studies tackling the basic mechanisms of their specific immunostimulatory effects. According to ZENG et al. (2015), in vivo studies have shown that aromatic plants have an inhibitory effect on pathogenic bacteria, Clostridium (C.) perfringens and E. coli in particular. Calendula (Calendula officinalis L.), dandelion (Taraxacum officinale Weber ex Wigg.), marigold (Tagetes erecta L.) and basil (Ocimum basilicum L.) are to medicinal plants. Various chemical compounds such as essential oils, carotenoids, flavonoids, terpenoids, coumarin, carbohydrates, lipids and amino acids that have multiple pharmacological effects, including anti-inflammatory, antioxidative, immunostimulatory, anticarcinogenic, antibacterial, antiviral and antifungal effects, have been detected in calendula flower petals (KHALID and da SILVA, 2012). In addition, based on in vitro studies, MULEY et al. (2009) report that polysaccharides extracted from calendula have an immunostimulatory effect. Studies 
performed to date have demonstrated the effect of calendula on immune response in poultry, manifested as an increase in the whole blood T lymphocyte count (APPLEGATE, 2009), while ARORA et al. (2013) demonstrated that calendula flowers inhibit E. coli growth in vitro. Dandelion root is believed to have favourable effect on the gastrointestinal system and to stimulate digestion and liver function, while dandelion leaves are used as a diuretic. YARNELL and ABASCAL (2009) point to the immunomodulatory effect of dandelions, whereas JASSIM et al. (2012) report the immunostimulatory effect of flavonoids as the active substances in dandelion flowers. Basil flavonoids have a modulatory role in some biological processes such as oxidation, enzyme detoxication, apoptosis, and host immune system reinforcement. These flavonoids are also known to improve intestinal mucosa morphology and function, to influence the size of immune organs, and help heat stress regulation in domestic animals (KAMBOH et al., 2015; SHARAFATI-CHALESHTORI et al., 2015). JAMROZ (2005) reports that flavonoids from basil leaves have an immunostimulatory effect and an important role in supporting cellular antioxidative mechanisms. KAMBOH and ZHU (2014) also showed that active substances such as isoflavones and flavanones had immunostimulatory effects, and could therefore be used as alternative in-feed additives in poultry production as promoters of intestinal health, and for improving the immune system. Marigolds are known for their high therapeutic values. This plant is rich in alkalonoids, terpenes, flavanoids and phenolic compounds (REGASWAMY and KOILPILLAI, 2014). CRAIG (1999) reports that plants rich in flavonoids, vitamin $\mathrm{C}$ or carotenoids can improve immune function, while flavonoids from plants can exert a mild anti-inflammatory action. Very few studies on the immunostimulatory mechanism of active plant substances have been published (HASHEMI and DAVOODI, 2012).

The aim of our study was to investigate and compare the effects of dried calendula, dandelion and marigold flowers, and of the plant basil on the kinetics of total leukocytes, helper and cytotoxic $\mathrm{T}$ lymphocytes, and B lymphocytes in peripheral blood, and to assess the $E$. coli colony forming unit (CFU) count in polled faecal samples of laying hens.

\section{Materials and methods}

Birds and diets. Laying hens of Tetra SL line, aged 25 weeks, were used in the study. Three hens were housed per cage, providing a stocking density of $610 \mathrm{~cm}^{2}$ of floor space/ hen. Five cages per treatment were randomly allocated to one of nine dietary treatments. The animals were divided into nine groups of 15 birds, as follows: a control group (CG) fed the regular mixture for laying hens; two experimental groups fed the regular mixture for laying hens with the addition of $1 \%(10 \mathrm{~g} / \mathrm{kg})$ and $3 \%(30 \mathrm{~g} / \mathrm{kg})$ chopped dandelion flowers (D1 and D3); two experimental groups fed the regular mixture with the addition of $1 \%(10 \mathrm{~g} / \mathrm{kg})$ and $3 \%(30 \mathrm{~g} / \mathrm{kg})$ chopped basil leaves (B1 and $\mathrm{B} 3)$; two 
M. Balenović et al.: Immunomodulatory and antimicrobial effects of selected herbs on laying hens

experimental groups fed the regular mixture with the addition of $1 \%(10 \mathrm{~g} / \mathrm{kg})$ and $3 \%$ $(30 \mathrm{~g} / \mathrm{kg})$ chopped calendula flowers $(\mathrm{C} 1$ and $\mathrm{C} 3)$; and two experimental groups fed the regular mixture with the addition of $1 \%(10 \mathrm{~g} / \mathrm{kg})$ and $3 \%(30 \mathrm{~g} / \mathrm{kg})$ chopped marigold flowers (M1 and M3). Laying hens had feed (Table 1) and water ad libitum throughout the 4-week study period. All the plants, i.e. calendula, marigold and dandelion flowers, and basil leaves, used as in-feed additives, were grown in 2014 on the test-field of the Department of Seed Science and Technology of the Faculty of Agriculture, University of Zagreb, Zagreb, Croatia. Plant material was dried at $35^{\circ} \mathrm{C}$ in a through-flow laboratory dryer for 24 hours and stored at $4{ }^{\circ} \mathrm{C}$ until use. It was cut into very small pieces in a knife mill immediately before being added to the feed mixture.

Table 1. Feed ingredients and calculated composition of standard diet used in the experiment

\begin{tabular}{|l|c|c|r|}
\hline \multirow{2}{*}{ Ingredient } & Content $(\mathrm{g} / \mathrm{kg})$ & \multicolumn{2}{|c|}{ Calculated composition } \\
\hline Maize & 645.2 & Crude protein, $\mathrm{g} / \mathrm{kg}$ & 149.1 \\
\hline Soybean meal & 175 & Crude fat, $\mathrm{g} / \mathrm{kg}$ & 23 \\
\hline Sunflower meal & 80 & Crude fibre, $\mathrm{g} / \mathrm{kg}$ & 26 \\
\hline Calcium carbonate & 80 & Crude ash, g/kg & 101 \\
\hline Monocalcium phosphate & 8 & Calcium, $\mathrm{g} / \mathrm{kg}$ & 34.2 \\
\hline Sodium chloride & 5 & Phosphorus, $\mathrm{g} / \mathrm{kg}$ & 5 \\
\hline DL methionine & 1.8 & Sodium, $\mathrm{g} / \mathrm{kg}$ & 1.9 \\
\hline Premix & 5 & Metabolic energy, $\mathrm{MJ} / \mathrm{kg}$ & 9.87 \\
\hline
\end{tabular}

${ }^{a}$ The premix provided per kg diet: Vitamin A 12000 IU; Vitamin D 1500 IU; Vitamin E 10 mg; Vitamin K 2 mg, Vitamin B 2 mg; Vitamin B 5 mg; Vitamin B 2 mg; Vitamin B 12 mg; Vitamin C 15 mg; Niacin 30 mg; Pantothenic acid $7 \mathrm{mg}$; Folic acid $0.5 \mathrm{mg}$; Biotin $0.05 \mathrm{mg}$; Choline $500 \mathrm{mg}$; I $0.5 \mathrm{mg}$; Fe $60 \mathrm{mg}$; Cu $3 \mathrm{mg}$; Mn $80 \mathrm{mg}$; Zn $50 \mathrm{mg}$; Co $0.15 \mathrm{mg}$; Se $0.15 \mathrm{mg}$.

Flow cytometry. Blood samples treated with citrate concentrated solution(BioReagent, suitable for coagulation assays, 4\% (w/v), Sigma-Aldrich, USA) were taken from randomly selected hens at the beginning of the study, and then on day 14 and day 28 , i.e. at the birds' ages of 25, 27 and 29 weeks. Monoclonal antibodies (mAb) against chicken $\mathrm{CD}$ antigens $\mathrm{CD} 45^{+}, \mathrm{CD}^{+}, \mathrm{CD}^{+}$and $\mathrm{CD} 21^{+}$(Southern Biotechnology Associates, Inc., Birmingham, USA) labelled with fluorescent dyes were used to determine total leukocyte count, T lymphocyte subpopulations and B lymphocytes. Leukocyte count in peripheral blood $(100 \mathrm{~mL})$ was determined by flow cytometry (Coulter EPICS-XL, Beckman Coulter, USA). Blood samples were diluted with phosphate buffer solution (PBS) to a leukocyte concentration of 5.0-9.7 $\times 10^{9} / \mathrm{L}$. Fifty $\mu \mathrm{L}$ of monoclonal antibodies against chicken $\mathrm{CD}^{+}$ lymphoid markers were added to $100 \mu \mathrm{L}$ of blood prepared in this way. All samples were done in triplicate and 10,000 cells from each sample were analysed by flow cytometry. 
Escherichia coli isolation from fecal samples. Faecal samples were taken on day 14 and day 28, i.e. at the birds' ages of 27 and 29 weeks. The samples were pooled and placed into an equal amount of buffered peptone water prewarmed to room temperature and mixed gently. $1 \mathrm{~g}$ of faecal sample was taken and dilutions made from $10^{-1}$ to $10^{-}$ 9. For E. coli isolation, the previously prepared faeces dilutions were inoculated onto solid selective and differential nutrient MacConkey agar (bioMérieux, France), chromogenic solid nutrient TBX agar, for isolation and enumeration (Tryptone Bile X-Gluc agar, bioMérieux, France), and solid nutrient PCA medium (Plate Count Agar, Tryptone glucose yeast agar, Oxoid, England). These media were incubated for 18-24 h at $37{ }^{\circ} \mathrm{C}$. Following incubation and counting the colonies grown on the media, several suspect colonies were inoculated on solid a non-selective media Columbia agar, with or without the addition of $5 \%$ to $10 \%$ defibrinated sheep blood (bioMérieux, France). These inoculated nutrient media were incubated for $18-24 \mathrm{~h}$ at $37^{\circ} \mathrm{C}$. Analytical Profile Index (API) test strips for Enterobacteriaceae, ID 32E consisting of 32 biochemical tests for automated identification by the ATB identification system (bioMérieux, France) were used for biochemical characterization of $E$. coli isolates grown on the Columbia agar.

Statistical analysis. The data collected were processed using Statistica 10 (StatSoft, Inc., 2011) reference statistical software. Basic data processing was performed by descriptive statistics methods. The t-test for dependent samples was used to determine the statistical significance of differences at the level of $\mathrm{P}<0.01$ between the control group and the experimental groups at the same time point, and between different experimental groups at different time points.

The study was conducted in line with the Act on the Protection of Animals Used for Experimental and Other Scientific Purposes (Official Gazette 47/11), issued by the Ministry of Agriculture, Republic of Croatia, which is in agreement with the respective European Union legislative.

\section{Results}

The kinetics of total leukocytes, helper T lymphocytes, cytotoxic T lymphocytes and B lymphocytes according to groups during the study period are presented in Figs 1, 2, 3 and 4, with the arithmetic mean, standard deviation and standard error for a particular group and time point. Fig. 5 presents the E. coli colony count $\left(\log \mathrm{CFU} \mathrm{g}{ }^{-1}\right)$ in pooled faecal samples of laying hens.

At the first time point (day 14), a statistically significant increase $(\mathrm{P}<0.01)$ was recorded as compared with the control group (CG) in total leukocyte count in all experimental groups, except for the groups administered 1\% chopped basil leaves (B1), and $1 \%$ and $3 \%$ chopped marigold flowers (M1 and M3). However, the results obtained at the second time point (day 28 ) revealed a statistically significantly higher total leukocyte 
count $(\mathrm{P}<0.01)$ as compared to the control group $(\mathrm{CG})$ in all experimental groups, with the exception of the group administered $1 \%$ and $3 \%$ marigold flowers. Comparison of the groups with different percentages of chopped plants indicated that the groups that received 3\% chopped dandelion flowers (D3), basil leaves (B3) and calendula flowers (C3) had higher total leukocyte count as compared with the groups that received $1 \%$ of the respective additives (D1, B1 and C1) (Fig. 1). Our results indicated the favourable effect of calendula and dandelion flowers and basil leaves on the activity of total leukocytes. Higher concentrations of dried plants resulted in higher leukocyte proliferation in the respective experimental groups, as compared with the levels recorded in the control group.

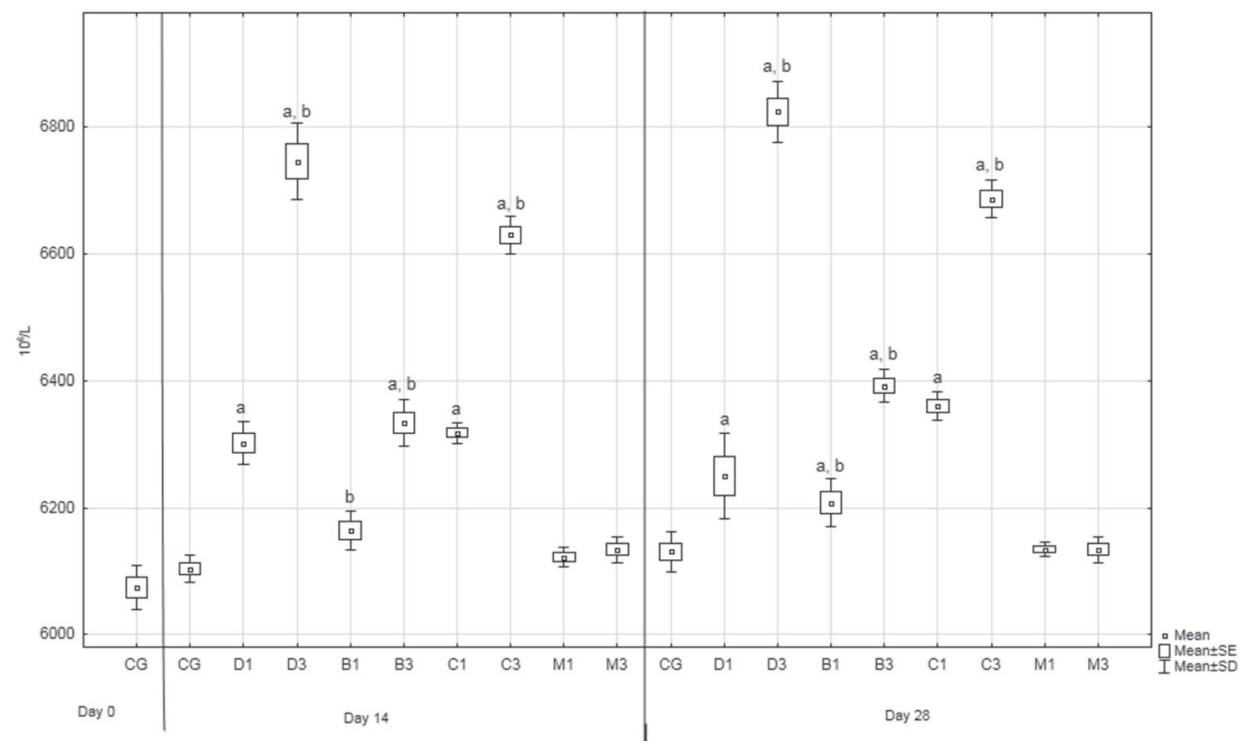

Fig. 1. Total leukocyte proportion in peripheral whole blood in the groups of 25 weeks old laying hens fed in-feed additives of 1\% and 3\% chopped dandelion flowers (D1 and D3), basil leaves (B1 and B3), calendula flowers ( $\mathrm{C} 1$ and $\mathrm{C} 3$ ) and marigold flowers (M1 and M3) on study days 0 , 14 and 28. ${ }^{a}$ Statistically significant higher value $(\mathrm{P}<0.01)$ in comparison to the value determined in the control group in the same period. ${ }^{\mathrm{b}}$ Statistically significant higher value $(\mathrm{P}<0.01)$ in relation to the day of sampling within the same group

At the first time point (day 14), the kinetics of helper T lymphocytes in the total cell population in the peripheral whole blood samples obtained from the laying hens showed no statistically significant difference $(\mathrm{P}<0.01)$ from the control group $(\mathrm{CG})$ in the experimental groups administered 1\% chopped basil leaves (B1) and 1\% chopped marigold flowers (M1). At the second time point (day 28), a statistically significantly 
higher $(\mathrm{P}<0.01)$ level of helper $\mathrm{T}$ lymphocytes was measured in all experimental groups as compared with the control group (CG). Comparison of helper T lymphocyte levels within the same group relative to the levels previously recorded on day 14 yielded statistically significantly higher values $(\mathrm{P}<0.01)$ in the groups receiving $1 \%$ and $3 \%$ chopped basil leaves (B), as well as in those receiving $1 \%$ and $3 \%$ chopped calendula flowers (C). The highest increase in helper $\mathrm{T}$ lympocytes was observed in the groups administered 3\% chopped dandelion (D) and calendula (C) flowers (Fig. 2).

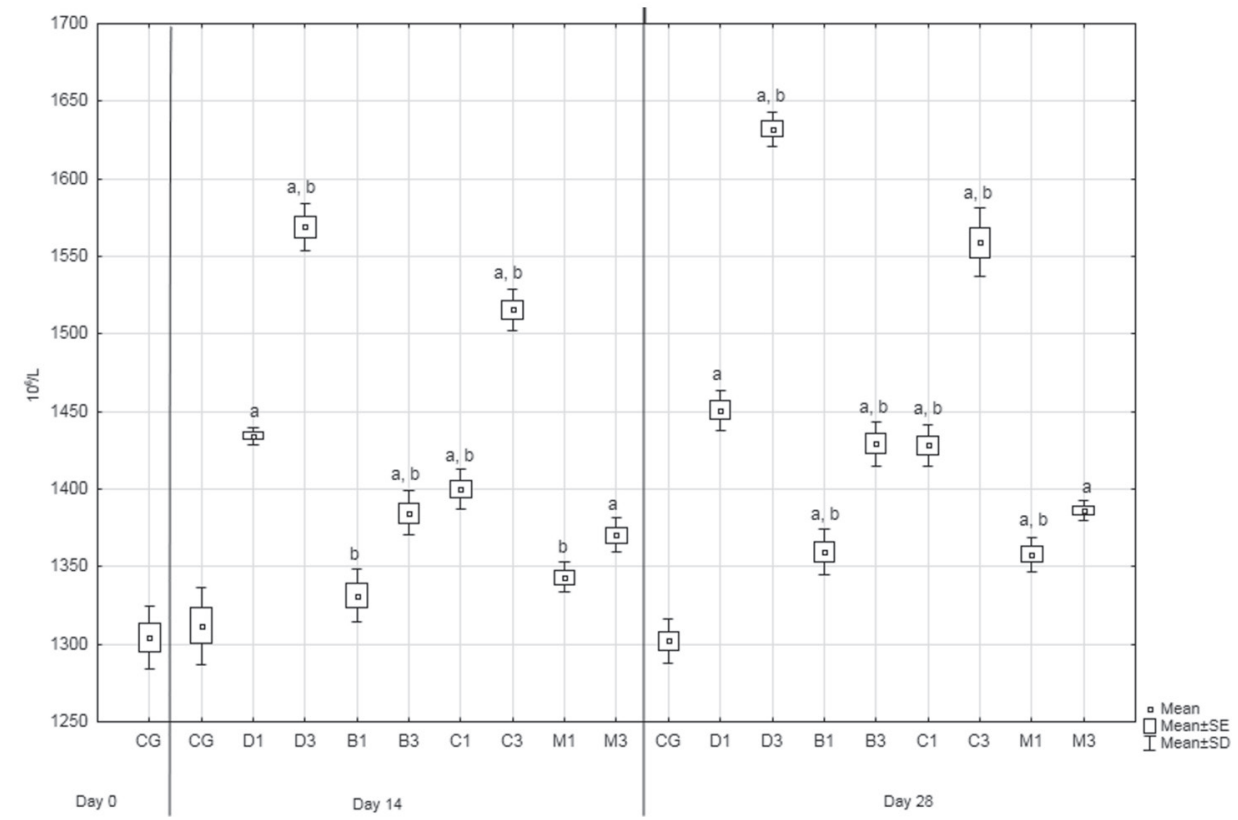

Fig. 2. Helper T lymphocyte proportion in a pooled homogeneous peripheral blood leukocyte sample in the groups of 25 week old laying hens fed in-feed additives of $1 \%$ and $3 \%$ chopped dandelion flowers (D1 and D3), basil leaves (B1 and B3), calendula flowers (C1 and C3) and

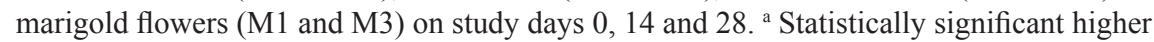
value $(\mathrm{P}<0.01)$ in comparison to the value determined in the control group in the same period. ${ }^{b}$ Statistically significant higher value $(\mathrm{P}<0.01)$ in relation to the day of sampling within the same group

Unlike helper T lymphocytes, the kinetics of cytotoxic $\mathrm{T}$ lymphocytes in the total cell population of the peripheral whole blood samples of laying hens yielded a statistically significantly higher level $(\mathrm{P}<0.01)$ in comparison with the control group in all groups, with the exception of the groups administered $1 \%$ and $3 \%$ chopped marigold flowers (M). Comparison of cytotoxic T lymphocyte levels within the same group relative to the levels 
M. Balenović et al.: Immunomodulatory and antimicrobial effects of selected herbs on laying hens

previously recorded on day 14 yielded statistically significantly higher values $(\mathrm{P}<0.01)$ in all experimental groups. Like helper $\mathrm{T}$ lymphocytes, the highest increase in cytotoxic $\mathrm{T}$ lymphocytes was recorded in the experimental groups receiving 3\% chopped dandelion (D) and calendula (C) flowers (Fig. 3).

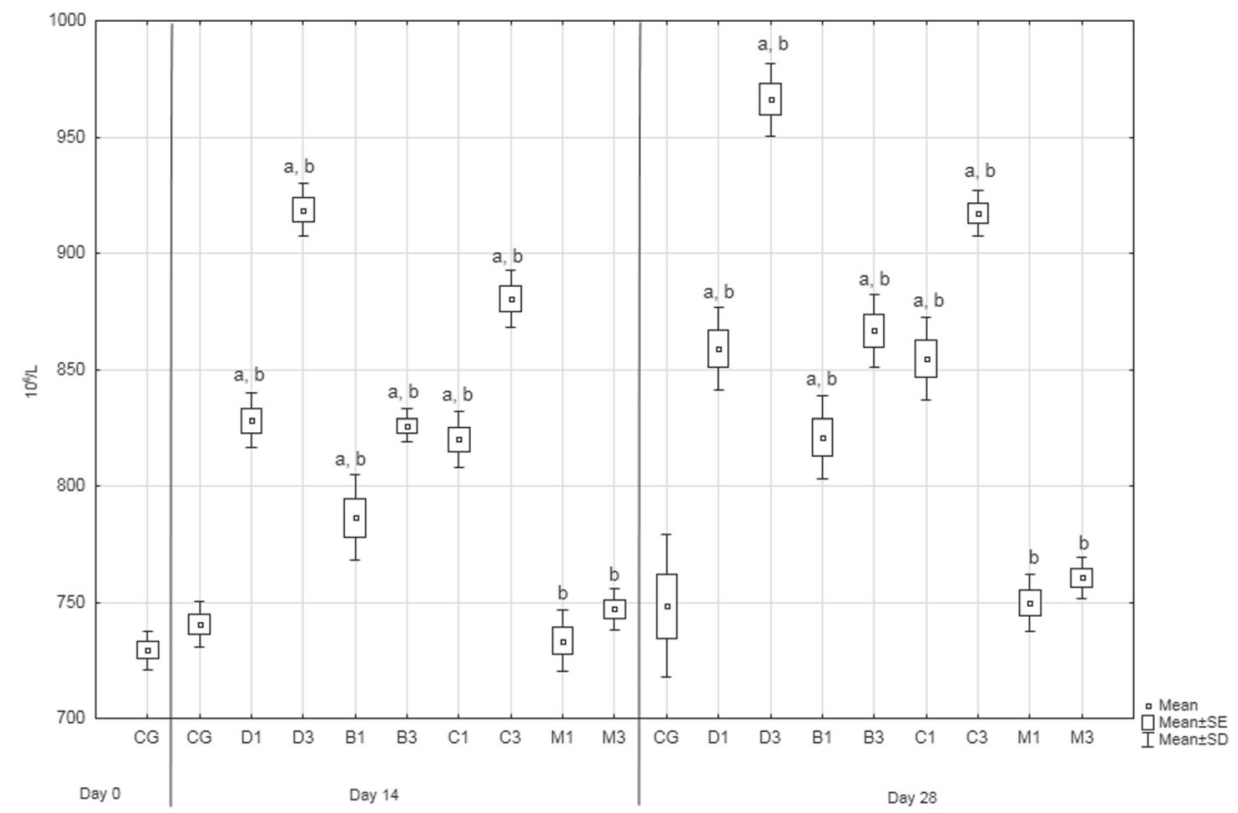

Fig. 3. Cytotoxic T lymphocyte proportion in a pooled homogeneous peripheral blood leukocyte sample in the groups of 25 weeks old laying hens fed in-feed additives of $1 \%$ and $3 \%$ chopped dandelion flowers (D1 and D3), basil leaves (B1 and B3), calendula flowers (C1 and C3) and marigold flowers (M1 and M3) on study days 0,14 and 28. ${ }^{\text {a }}$ Statistically significant higher value

$(\mathrm{P}<0.01)$ in comparison to the value determined in the control group in the same period.

However, the effect of plant in-feed additives on the kinetics of B lymphocytes was less noticeable. A statistically significant increase $(\mathrm{P}<0.01)$ was only recorded in the groups administered 3\% chopped dandelion (D3) and 1\% and 3\% calendula (C1 and C3) flowers (Fig. 4).

In our study, bacteriological testing of faecal samples for the presence of $E$. coli showed a decrease in E. coli $\mathrm{CFU}$ count in all experimental groups as compared with the control group at both time points (days 14 and 28). The greatest reduction in E. coli CFU count in pooled faecal samples was recorded in the experimental group administered the in-feed additive of $1 \%$ ground basil leaves (Fig. 5). 
M. Balenović et al.: Immunomodulatory and antimicrobial effects of selected herbs on laying hens

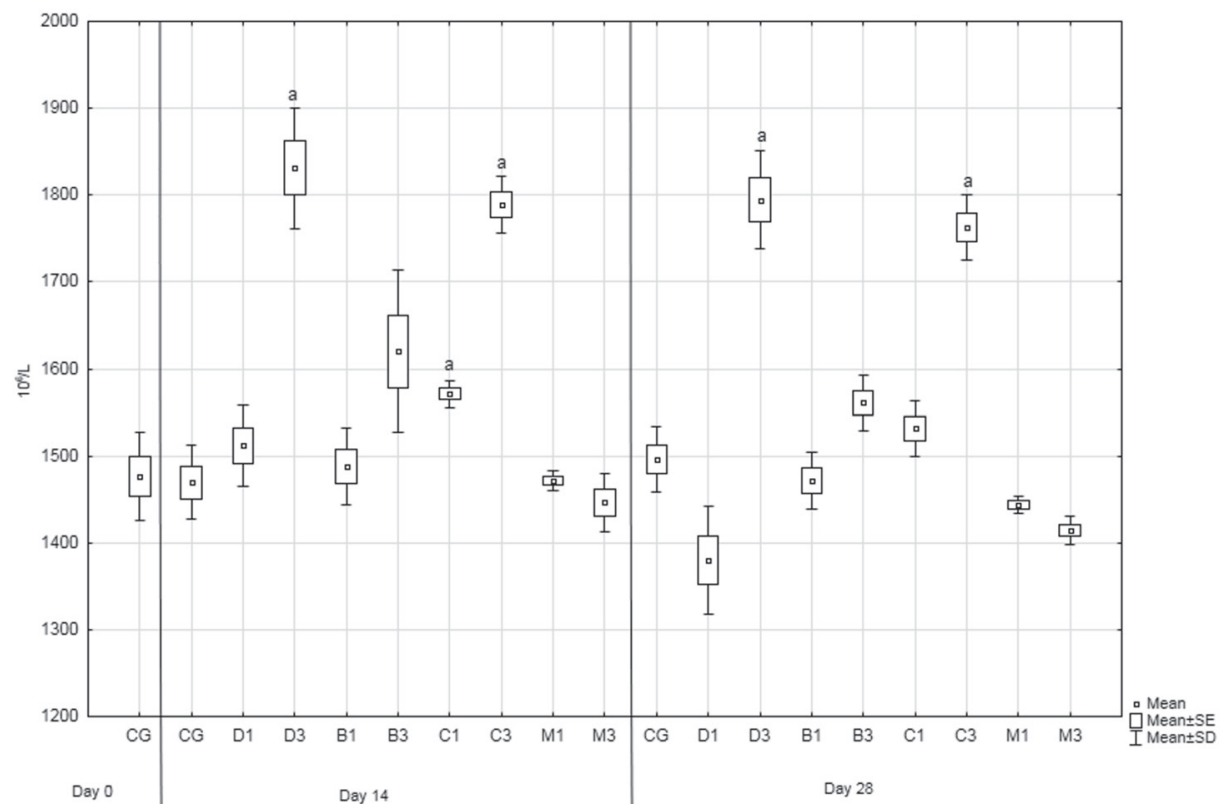

Fig. 4. B lymphocyte proportion in a pooled homogeneous peripheral whole blood leukocyte sample in the groups of 25 week old laying hens fed in-feed additives of $1 \%$ and $3 \%$ chopped dandelion flowers (D1 and D3), basil leaves (B1 and B3), calendula flowers (C1 and C3) and marigold flowers (M1 and M3) on study day 0, 14 and 28. CG, control group; D1, 1\% dandelion flower; D3, 3\% dandelion flower; B1, 1\% basil leaf; B3, 3\% basil leaf; $\mathrm{C} 1,1 \%$ calendula flower; $\mathrm{C} 3,3 \%$ calendula flower; M1, 1\% marigold flower; M3, 3\% marigold flower.


Fig. 5. Escherichia coli (E. coli) colony count (log CFU g-1) in pooled faecal samples of laying hens fed in-feed additives of $1 \%$ and 3\% chopped dandelion flowers (D1 and D3), basil leaves (B1 and B3), calendula flowers (C1 and C3) and marigold flowers (M1 and M3) on study days 14 and 28. 
M. Balenović et al.: Immunomodulatory and antimicrobial effects of selected herbs on laying hens

\section{Discussion}

Studies conducted to date have confirmed that phytobiotics have an immunostimulatory effect, which manifests as improved activity of lymphocytes, macrophages and natural killer cells, increased phagocytosis, or interferon synthesis stimulation (VIDANARACHCHI et al., 2005; GRASHORN, 2010; HASHEMI and DAVOODI, 2010; KUMAR et al., 2014; DIAZ-SANCHEZ et al., 2015; YITBAREK, 2015). Inspired by these data, we embarked upon this study to find out whether dried calendula, dandelion and marigold flowers and dried basil leaves added to poultry feed influence the kinetics of total leukocytes, helper and cytotoxic T lymphocytes, and B lymphocytes in peripheral blood. Our results confirmed those reported by APPLEGATE et al. (2010), who demonstrated the effect of phytogenic products on intestinal microflora, feed digestibility and intestinal morphology, and thus on immunity, depending on the amount added to feed or drinking water. Active ingredients are known to accumulate in essential oils, thus using these oils enables administration of lower doses of up to $1 \mathrm{~g} / \mathrm{kg}$ feed, whereas whole plants or their parts are generally used in higher doses. CROSS et al. (2007) observed the favourable effects of using different plants, including marjoram, oregano, cabbage-rose, rosemary and common thyme in doses of 1 to $10 \mathrm{~g} / \mathrm{kg}$, depending on whether whole or ground plants or their distilled extracts were used. Our study results suggest that laying hens fed a higher dose of dried plants achieved greater whole blood leukocyte proliferation. Numerous authors report that phytobiotics, that is, the action of their active substances, inhibit $E$. coli activity (JAMROZ, 2005; HASHEMI and DAVOODI, 2010; HASHEMI and DAVOODI, 2012; DIAZ-SANCHEZ et al., 2015). According to JAMROZ (2005) and WINDISCH et al. (2008), the effect of these active substances manifests as enhanced excretion of endogenous enzymes, and improved appetite, digestibility and absorption of nutrients, improved intestinal microflora, reduced E. coli and Clostridium populations, and stimulation of Lactobacillus spp. proliferation, and antibacterial and antiviral action, thus stimulating the animal immune system. Similar results have been reported by RAHIMI et al. (2011) investigating the effects of three plants (common thyme, garlic and echinacea) on E. coli in broiler chickens. Bacteriological testing showed a significantly lower E. coli $\mathrm{CFU}$ count in treated groups as compared with the control group.

Antimicrobial activity and immunostimulatory action are probably the two main mechanisms by which phytobiotics exert their favourable impact on the economic growth and health of animals (FALLAH et al., 2013). Considering all our results, we are inclined to conclude that the calendula and dandelion in-feed additives resulted in the highest total leukocyte and $\mathrm{T}$ lymphocyte proliferation in the laying hens (in the groups administered $3 \%$ chopped plants in particular), whereas the in-feed additive of $1 \%$ basil leaves exerted the strongest antibacterial action, although an antibacterial effect was recorded for all study plants. All these findings clearly indicate the justifiable addition of plants, i.e. 
flavonoids as their active ingredients, to animal feed because of their antimicrobial and immunostimulatory actions. However, it is necessary to take into consideration the type of plant, the active substance composition, and the potential toxicity for the host. Generally, phytogenic in-feed additives have favourable effects but the knowledge of their use in poultry feeding is still inadequate, thus requiring additional research, along with farmer support in the production of feed additives from locally available plants and flavours. Our study, as well as those of other researchers (ALLOUI et al., 2014; YITBAREK, 2015) indicate that phytobiotics, also known as phytogenic natural growth promoters, might be combined with other feed additives, such as probiotics or prebiotics, in order to achieve better results in poultry production. Future research should be aimed at the efficiency of feed supplementation, with combinations of the herbs that have shown positive effects on laying hens when given separately in this study.

\section{References}

ALlOUI, N., M. N. ALLOUI, A. AGABOU (2014): Application of herbs and phytogenic feed additives in poultry production - a review. Glob. J. Anim. Sci. Res. 2, 234-243.

APPLEGATE, T. J. (2009): Influence of phytogenics on the immunity of livestock and poultry. In: Phytogenics in Animal Nutrition. (Steiner, T., Ed.), Nottingham Univ. Press, Nottingham, UK, pp. 39-59.

APPlegAte, T. J., V. KLOSE, T. STEINER, A. GANNER, G. SCHATZMAYR (2010): Probiotics and phytogenics for poultry: myth or reality? J. Appl. Poult. Res. 19, 194-210.

DOI: $10.3382 /$ japr.2010-00168

ARORA, D.,A. RANI,A.SHARMA(2013): Areview on phytochemistry and ethnopharmacological aspects of genus Calendula. Pharmacogn Rev. 7, 179-187.

ASHAYERIZADEH, O., B. DASTAR, M. S. SHARGH, A. ASHAYERIZADEH, E. RAHMATNEJAD, S. M. R. HOSSAINI (2009): Use of garlic (Allium sativum), black cumin seeds (Nigella sativa l.) and wild mint (Mentha longifolia) in broiler chickens diets. J. Anim. Vet. Adv. 9, 1860-1863.

CRAIG, W. J. (1999): Health-promoting properties of common herbs. Am. J. Clin. Nutr. 70 (Suppl), 491S-499S.

DOI: $10.1093 / \mathrm{ajcn} / 70.3 .491 \mathrm{~s}$

CROSS, D. E., R. M. McDEVITT, K. HILLMAN, T. ACAMOVIC (2007): The effect of herbs and their associated essential oils on performance, digestibility and gut microflora in chickens 7 to 28 days of age. Br. Poult. Sci. 48, 496-506.

DOI: $10.1080 / 00071660701463221$

DIAZ-SANCHEZ, S., D. D'SOUZA, D. BISWAS, I. HANNING (2015): Botanical alternatives to antibiotics for use in organic poultry production. Poult. Sci. 94, 1419-1430.

DOI: $10.3382 / \mathrm{ps} /$ pev014 
M. Balenović et al.: Immunomodulatory and antimicrobial effects of selected herbs on laying hens

FALLAH, R., A. KIANI, A. AZARFAR (2013): A review of the role of five kinds of alternatives to in-feed antibiotics in broiler production. J. Vet. Med. Anim. Health 5, 317-321.

DOI: $10.5897 / J V M A H 2013.0237$

FERKET, P. R. (2004): Alternatives to antibiotics in poultry production: responses, practical experience and recommendations. In: Biotechnology in Feed Industry. (Lyons, T. P., K. A. Jacques, Eds.), Nottingham University Press, Nottingham, UK, pp. 57-67.

HASHEMI, S. R., H. DAVOODI (2010): Phytogenics as new class of feed additive in poultry industry. J. Anim. Vet. Adv. 9, 2295-2304.

DOI: 10.3923 javaa.2010.2295.2304

HASHEMI, S. R., H. DAVOODI (2012): Herbal plants as new immuno-stimulator in poultry industry: a review. Asian J. Animal Vet. Adv. 7, 105-116.

DOI: 10.3923/ajava.2012.105.116

GRASHORN, M. A. (2010): Use of phytobiotics in broiler nutrition - an alternative to infeed antibiotics? J. Anim. Feed Sci. 19, 338-347.

DOI: $10.22358 / \mathrm{jafs} / 66297 / 2010$

JAMROZ, D. (2005): Nutritional factors supporting the immune response in animals. Krmiva 47, 207-219.

JANKOWSKI, J., M. KUBIŃSKA, Z. ZDUŃCZYK (2014): Nutritional and immunomodulatory function of methionine in poultry diets - a review. Ann. Anim. Sci. 14, 17-31.

DOI: 10.2478 /aoas-2013-0081

JASSIM, A. K. M. N., S. A. FARHAN, O. M. NOORI (2012): Identification of dandelion Taraxacum officinale leaves components and study of its extract effects on different microorganisms. J. Al-Nahrain Univ. 15, 7-14.

KAMBOH, A. A., W. Y. ZHU (2014): Individual and combined effects of genistein and hesperidin on immunity and intestinal morphometry in lipopolysacharide-challenged broiler chickens. Poult. Sci. 93, 2175-2183.

DOI: $10.3382 /$ ps.2014-03971

KAMBOH, A. A., M. A. ARAIN, M. J. MUGHAL, A. ZAMAN, Z. M. ARAIN, A. A. SOOMRO (2015): Flavonoids: health promoting phytochemicals for animal production - a review. J. Anim. Health Prod. 3, 6-13.

DOI: $10.14737 /$ journal.jahp/2015/3.1.6.13

KHALID, K. A., J. A. TEIXEIRA da SILVA (2012): Biology of Calendula officinalis Linn.: Focus on pharmacology, biological activities and agronomic practices. Med. Aromat. Plant. Sci. Biotechnol. 6, 12-27.

KUMAR, M., V. KUMAR, D. ROY, R. KUSHWAHA, S. VAISWANI (2014): Application of herbal feed additives in animal nutrition - a review. Int. J. Livest. Res. 4, 1-8.

DOI: $10.5455 /$ ijlr.20141205105218 
M. Balenović et al.: Immunomodulatory and antimicrobial effects of selected herbs on laying hens

KOUTSOS, E. A., K. C. KLASING (2008): Factors modulating the avian immune system. In: Avian Immunology. (Davison, F., B. Kaspers, K. A. Schat, Eds.), Academic Press, Elsevier Ltd., pp. 323-338.

MULEY, B. P., S. S. KHADABADI, N. B. BANARASE (2009): Phytochemical constituents and pharmacological activities of Calendula officinalis Linn (Asteraceae): a review. Trop. J. Pharm. Res. 8, 455-465.

DOI: $10.4314 /$ tjpr.v8i5.48090

RAHIMI S., Z. TEYMOURI ZADEH, M. A. KARIMI TORSHIZI, R. OMIDBAIGI, H. ROKNI (2011): Effect of the three herbal extracts on growth performance, immune system, blood factors and intestinal selected bacterial population in broiler chickens. J. Agr. Sci. Tech. $13,527-539$.

REGASWAMY, D., J. KOILPILLAI (2014): Physicochemical screening of Tagetes erecta Linn. Proceedings of the World Congress on Engineering 2014, Vol I, WCE 2014, 2-4 Jul. 2014, London, UK, 642-644.

SHARAFATI-CHALESHTORI, S., N. ROKNI, M. RAFIEIAN-KOPAEI, F. DREES, E. SALEHI (2015): Antioxidant and antibacterial activity of basil (Ocimum basilicum L.) essential oil in beef burger. J. Agr. Sci. Tech. 17, 817-826.

VIDANARACHCHI, J. K., L. L. MIKKELSEN, I. SIMS, P. A. IJI, M. CHOCT (2005): Phytobiotics: alternatives to antibiotic growth promoters in monogastric animal feeds. Recent Adv. Animal Nutr. Aust. 15, 131-144.

WINDISCH, W., K. SCHEDLE, C. PLITZNER, A. KROISMAYR (2008): Use of phytogenic products as feed additives for swine and poultry. J. Anim. Sci. 86 (E. Suppl.), E140-E148.

DOI: $10.2527 /$ jas.2007-0459

YANG, Y., P. A. IJI, M. CHOCT (2009): Dietary modulation of gut microflora in broiler chickens: a review of the role of six kinds of alternatives to in-feed antibiotics. World Poult. Sci. J. 65, 97-114.

DOI: $10.1017 / \mathrm{S} 0043933909000087$

YARNELL, E., K. ABASCAL (2009): Dandelion (Taraxacum officinale and T. mongolicum). Integ. Med. 8, 35-38.

YITBAREK, M. B. (2015): Phytogenics as feed additives in poultry production: a review. Int. J. Ext. Res. 3, 49-60.

ZENG, Z., S. ZHANG, H. WANG, X. PIAO (2015): Essential oil and aromatic plants as feed additives in non-ruminant nutrition: a review. J. Anim. Sci. Biotechnol. 6, 7.

DOI: $10.1186 / \mathrm{s} 40104-015-0004-5$

Received: 2 December 2017

Accepted: 17 May 2018

Vet. arhiv 88 (5), 673-686, 2018 
M. Balenović et al.: Immunomodulatory and antimicrobial effects of selected herbs on laying hens

\section{BALENOVIĆ, M., V. SAVIĆ, Z. JANJEČIĆ, M. POPOVIĆ, B. ŠIMPRAGA, K. CAROVIĆ-STANKO, D.BEDEKOVIĆ, T.AMŠELZELENIKA:Imunostimulacijski i antimikrobni učinci biljaka na kokoši nesilice. Vet. arhiv 88, 673-686, 2018.}

\section{SAŽETAK}

Cilj istraživanja bila je učinkovitost osušenog cvijeta nevena (Calendula officinalis L.), maslačka (Taraxacum officinale Weber ex Wigg.), kadifice (Tagetes erecta L.) i lišća bosiljka (Ocimum basilicum L. cv. Genovese), dodanih u hranu za konzumne nesilice, na kinetiku ukupnih leukocita, pomoćničkih i citotoksičnih T-limfocita, kao i B-limfocita u perifernoj krvi, te utvrditi broj kolonija E. coli u fecesu. U istraživanju su korištene konzumne nesilice linije Tetra SL u dobi od 25 tjedana, koje su bile raspodijeljene u devet skupina po 15 ptica. Nesilice su hranjene uobičajenom smjesom za nesilice uz dodatak $1 \%$ (10 g/kg) i $3 \%(30 \mathrm{~g} / \mathrm{kg})$ nasjeckanih cvjetova i lišća navedenih biljaka. Imunostimulacijski i antimikrobni učinci ljekovitog bilja na konzumne nesilice praćeni su određivanjem prethodno navedenih pokazatelja na početku pokusa te 14 . i 28. dana pokusa, odnosno u dobi konzumnih nesilica od 25, 27 i 29 tjedana. Dobiveni rezultati pokazuju da su dodaci nasjeckanih cvjetova nevena i maslačka u prehrani peradi, osobito u skupinama s $3 \%$ nasjeckane biljke, potaknuli najveću proliferaciju ukupnih leukocita, T-limfocita i B-limfocita $(\mathrm{P}<0,01)$. Antibakterijsko djelovanje najviše se očitovalo upotrebom 1\% dodatka bosiljka, iako su sve biljke djelovale antibakterijski. Rezultati pokazuju da je nepobitno utvrđena opravdanost primjene biljaka u krmnim smjesama zbog njihova antimikrobnog, ali i imunostimulacijskog učinka. Fitogeni dodaci hrani imaju pozitivne učinke, ali spoznaja o njihovoj upotrebi u hranidbi peradi i dalje je nedovoljna i zahtijeva daljnja istraživanja te se može zaključiti da bi se fitobiotici, koji se nazivaju i fitogeni prirodni promotori rasta, mogli kombinirati s drugim dodacima u hrani, kao što su probiotici ili prebiotici, čime bi se postigli bolji proizvodni pokazatelji u peradarskoj proizvodnji.

Ključne riječi: ljekovito bilje; imunostimulacijski učinak; antimikrobni učinak; konzumne nesilice 